\title{
Influence of Materials in Life Cycle Energy Assessment of a Six Storey Building
}

\author{
PL. Meyyappan, C. Sivapragasam
}

\begin{abstract}
Life Cycle Energy Assessment (LCEA) is one of the evaluating tools for assessing environmental impact of various types of materials used in the buildings components. The LCEA is based on reduction of total amount of energy consumed during the life cycle of building. Operational phase has been taken and the energy consumed for the phase has been evaluated in this study for three cases with respect to change in materials. This mainly focuses on the change in the energy consumption due to the usage of RCC and Wood materials in various building component such as roofs and infill walls etc. under Indian conditions. A six storey building with a plan dimension of $48 m \times 24 m$ is considered. The 'eQuest' is the quick energy simulation tool which is widely used to calculate the whole building's energy performance. This tool is used to estimate the energy consumption in month wise on various aspects.
\end{abstract}

\section{Keywords : LCEA, Building, Operational Phase, eQuest}

\section{INTRODUCTION}

Lcais CA is a technique used to assess the environmental effect due to the construction of building. LCA based studies have been done all over the world but they are only limited, focusing only the study about how the material been releasing energy in each stages of life cycle than focusing on sustainable building concept [1]-[3]. The previous studies are mainly based on LCA and basic calculation of operational energy. LCEA is used to calculate the energy been consumed during the phases of the building which helps to analyze the effects on environment. Most of studies reveal the usage of eQUEST software for the energy simulation and focuses on the conditions similar to the American and Canadian states [7]. But in this study, detailed calculation has been carried out by using different materials as the components of the building. Among the different stages of the building operational phase is main aspect in terms of maximum energy consumption. The operational phase energy is evaluated by using eQUEST software [5].

In India such concepts are not considered as the major task, but this energy plays a major role in environmental impacts [6]. In this study, an attempt is made to study the operational phase of LCEA for a six storey building in eQuest software. This study is the extensions of our preliminary work [8] to see the effect in terms of various components of energy consumption, if the numbers of stories are increased.

Revised Manuscript Received on December 5, 2019

* Correspondence Author

PL. Meyyappan*, Civil department, Kalasalingam Academy of Research and Education, Krishnankoil, India. Email: meyyappan@klu.ac.in

C. Sivapragasam, Civil department, Kalasalingam Academy of Research and Education, Krishnankoil, India. Email: sivapragasam@klu.ac.in

\section{BUILDING DETAILS}

In this study, the six storey civil department building at Kalasalingam Academy of Research and Education, Krishnankoil is considered. The building has the plan area 48 $\mathrm{m} \times 21 \mathrm{~m}$ and height is $21 \mathrm{~m}$. The floor and roof slab has thickness of $150 \mathrm{~mm}$. The plan view of a first floor and elevation of a building is shown in Figure 1 and 2.

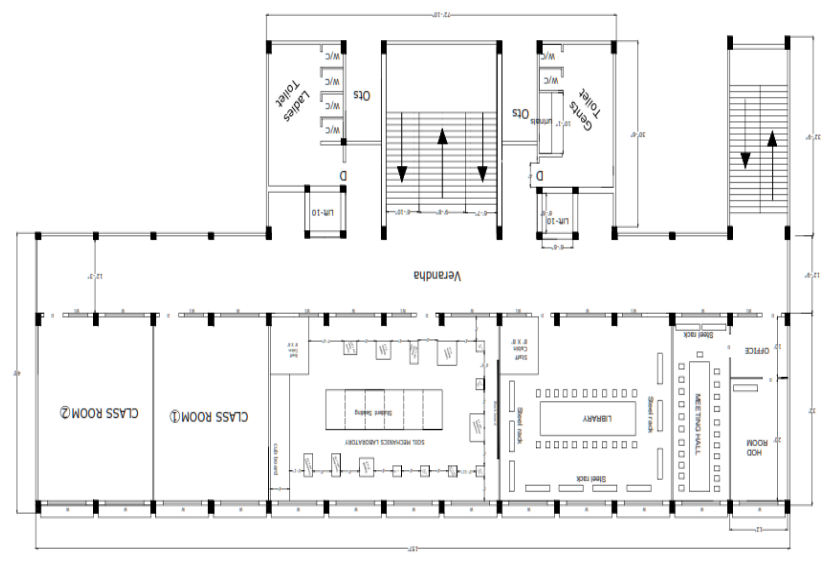

Fig. 1.Plan view of the building (First floor)

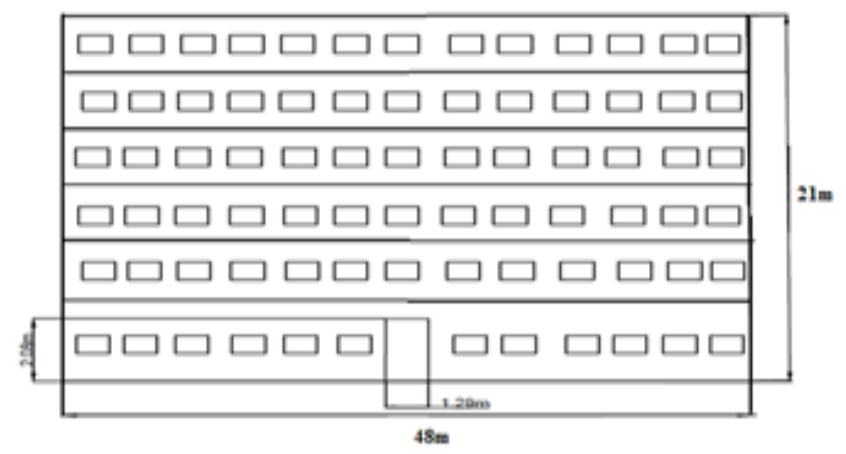

Fig. 2.Elevation of the building

\section{INPUT DETAILS IN EQUEST}

For this study, the energy simulation tool used is eQUEST. This allows the user to import each and every information of building geometry and its architectural model. The software has two types of wizard i.e schematic wizard and design development wizard. The first phase (the Building creation wizard) allows the user to import details about the type of building, purpose of usage, location of the building , area and storey of the building, codal provisions, type of electrical and gas utilizes, size of each and every room, 
occupancy of the room, direction of the building, direction and size of doors and windows, type of material used in construction of the building, and type of doors and windows, type of HVAC systems, size of the HVAC system and electrical load based on usage etc., The second phase asks the measure category. The third phases ask to simulate the inputs. The last and final phase gives the results on energy consumption. Figure 3 shows the different stages of input details in eQUEST simulation tool.

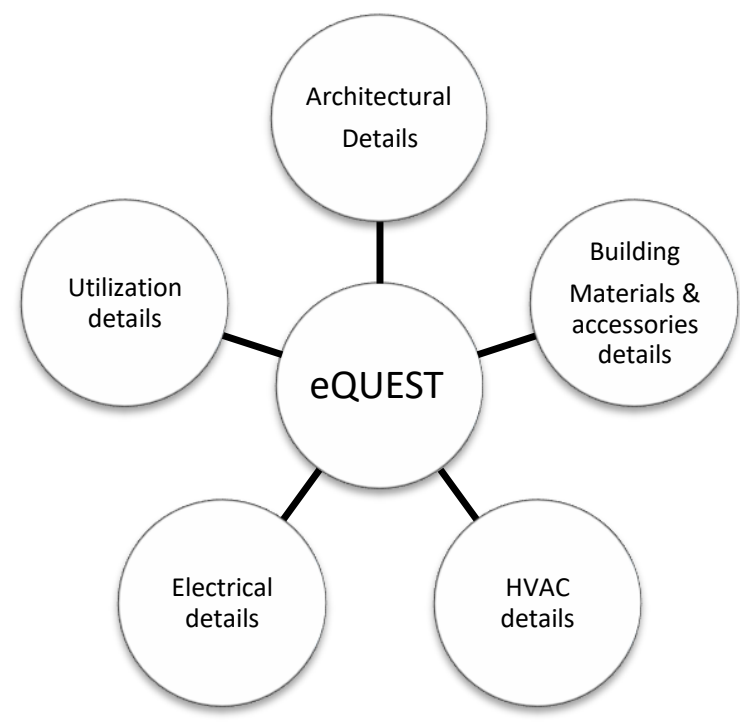

Fig. 3.Stages of Input Details in eQuest

Table- I: Summary Input Details

\begin{tabular}{|c|c|c|}
\hline \multirow{2}{*}{ S.no } & \multicolumn{2}{|c|}{ I. Architectural details } \\
\hline & Parameters & Data \\
\hline 1 & Building Area & 12500 sq.ft \\
\hline 2 & Number of floors & $\begin{array}{l}\text { Above Grade: } 6 \\
\text { Below Grade: } 0\end{array}$ \\
\hline 3 & Foot print shape & Rectangular \\
\hline 4 & Zoning pattern & One per floor \\
\hline 5 & Building orientation & Plan north \\
\hline 6 & Footprint dimensions & $\begin{array}{l}X=48 \mathrm{~m} \\
Z=24 \mathrm{~m}\end{array}$ \\
\hline 7 & Floor to floor height & $3.5 \mathrm{~m}$ \\
\hline 8 & $\begin{array}{l}\text { Floor to ceiling } \\
\text { height }\end{array}$ & $3.5 \mathrm{~m}$ \\
\hline \multicolumn{3}{|c|}{ II. Building Materials and Accessories Details } \\
\hline 9 & Roof surface & Concrete, Wooden \\
\hline 10 & Infill walls & Masonry, wooden \\
\hline 11 & Slab thickness & 6 inches \\
\hline 12 & Tiles type & Ceramic \\
\hline 13 & Door type & Single leaf glass \\
\hline 14 & Door direction & North \\
\hline 15 & Door size & $0.9 \mathrm{~m} \times 2.1 \mathrm{~m}$ \\
\hline 16 & Window size & $1.8 \mathrm{~m} \times 1.2 \mathrm{~m}$ \\
\hline 17 & Window position & $0.75 \mathrm{~cm}$ (Sill height) \\
\hline 18 & Window direction & As per plan \\
\hline \multicolumn{3}{|c|}{ III. HVAC Details } \\
\hline 19 & Cooling source & DX Coil \\
\hline
\end{tabular}

\begin{tabular}{|l|l|l|}
\hline 20 & Heating source & Nil \\
\hline 21 & Cool system type & Split single \\
\hline 22 & $\begin{array}{l}\text { Thermostat set points } \\
\text { range }\end{array}$ & $75^{\circ} \mathrm{F}$ to $85^{\circ} \mathrm{F}$ \\
\hline 23 & $\begin{array}{l}\text { Cooling } \\
\text { temperature }\end{array}$ & $65^{\circ} \mathrm{F}$ to $75^{\circ} \mathrm{F}$ \\
\hline 24 & Air path & Direct \\
\hline 25 & Air flow & $0.50 \mathrm{cfm} / \mathrm{sqft}$ \\
\hline 26 & Efficiency & 1 (HVAC) \\
\hline IV. Electric and its Utilization Details \\
\hline 27 & Lighting load & $2.798 \mathrm{~W} / \mathrm{sq} \cdot \mathrm{m}$ \\
\hline 28 & Plug load & $40.036 \mathrm{~W} / \mathrm{sq} \cdot \mathrm{m}$ \\
\hline 29 & Design Occupancy & 12.21 sq.m $/$ person \\
\hline 30 & Occupancy & $100 \%$ \\
\hline 31 & Electric usage & 8.00 am to $6.00 \mathrm{pm}$ \\
\hline 32 & Days & Mon to Sun \\
\hline 33 & Season & 12 months \\
\hline 34 & HVAC timings & 7.00 am to $11.00 \mathrm{am}$ \\
\hline
\end{tabular}

Table 1 shows the summary of various input parameters and the concerned data to be fed in eQUEST simulation tool. The architectural details of the building include building area, number of floors, shape of the building, pattern of the zone, orientation of the building, dimensions, height etc., The materials used in various parts of the building includes materials on the roof surface, infill walls, size of the thickness, tiles type, door size and type, window type and size, position of the window and door etc. The details about the HVAC systems includes efficiency and type of cooling source, thermostat set points, cooling design temperature, air path, air flow etc., are given The electrical details include lighting load, plug load, occupancy details, electrical usage days and timings, seasonal details, air conditioner usage timings etc..

\section{A. Limitations of eQUEST}

The HVAC system does not contain any optional requirements for the usage of ceiling fans. Therefore based on the equivalent air conditioning systems only input has to be given. For 8 hours usage of ceiling fans, the energy consumed is made equivalent to 1 hour of usage of air conditioning systems. Different varieties of glasses cannot be featured in the eQUEST and it will take the standard normal glass only. Further it is also not possible to give half paneled glass in window and door accessories. It is only possible to give only fully paneled glass accessories or opaque materials.

\section{Operational Phase Of lCea Study}

The six storey building of the plan dimension $48 \mathrm{~m} \times 24 \mathrm{~m}$ is taken for evaluating the operational phase of LCEA stusy using eQUEST. It is obtained based on the inputs shown in the Table 1. The created building model in eQUEST is shown in Figure 4. Trials are made based on the effect of different materials. Three cases have been considered. Figure 5 is the part of the wizard screen in schematic design wizard in eQUEST software for change in materials.

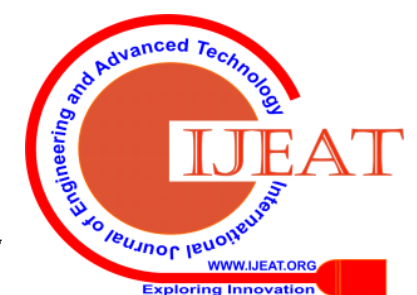


In case 1 , roof slab of the building is considered to be made up of RCC material and the infill walls are made up of masonry material.

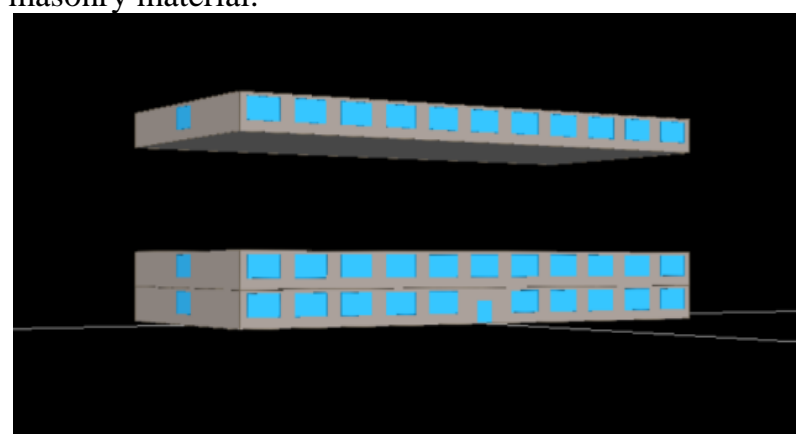

Fig. 4. Building Model

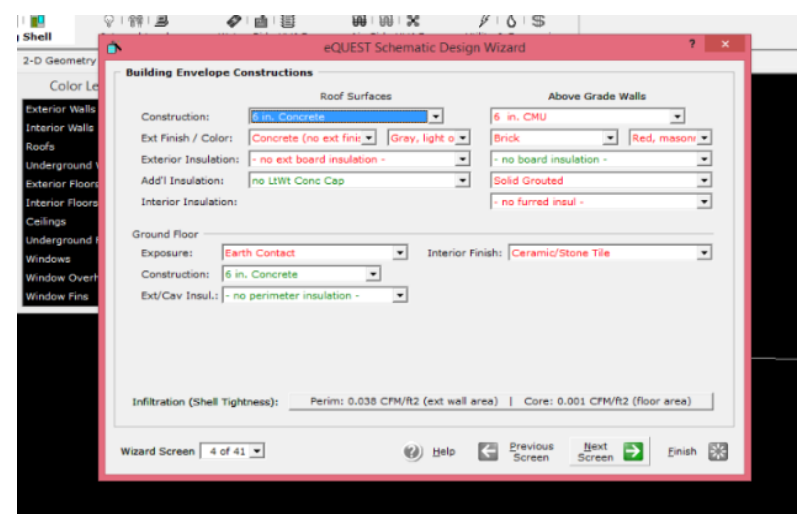

Fig. 5.Snap shot for the material change wizard

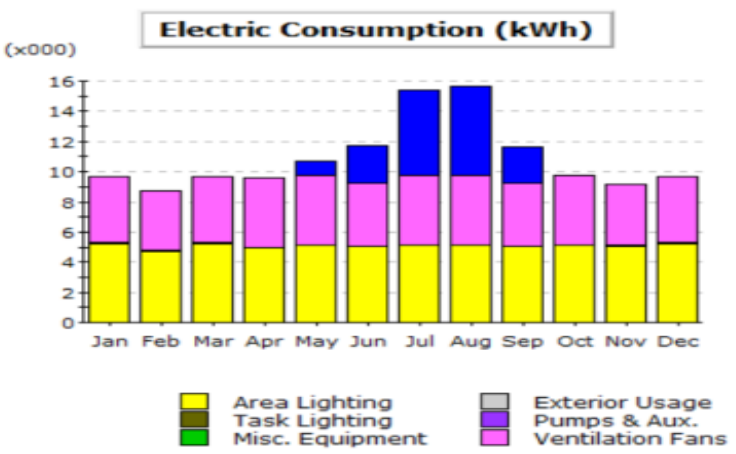

Fig. 6.Electrical consumption for case 1

In case 2 , the masonry infill wall is changed to wooden infill wall.

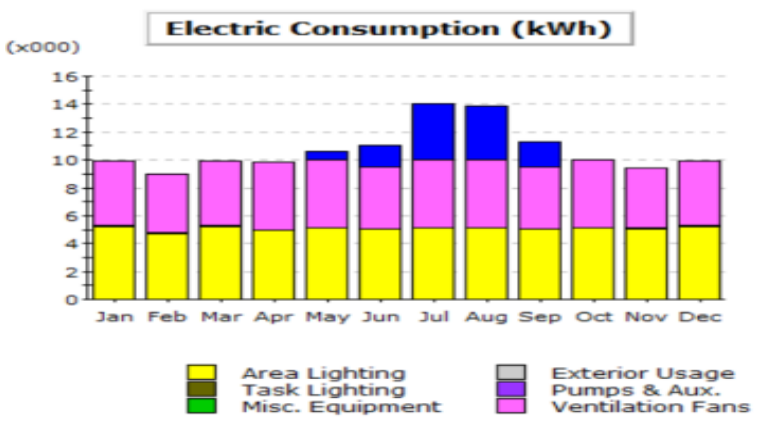

Fig. 7. Electrical Consumption for Case 2

Finally, in the case 3, both the roof and infill wall of the building is considered to be of wooden material. The effect of the change in materials has given different in results. These trials help to sort out the effective use of materials.

\section{A. Result and Discussions}

The energy consumed during the operational phase has been analyzed in the eQUEST software. The results are based on monthly consumption per annum. The Table 5 shown results for annual usage of energy for the trials made.

Table- II: Results of Annual Energy Consumption for all cases

\begin{tabular}{|l|l|l|l|l|}
\hline \multirow{2}{*}{ S.no } & \multicolumn{4}{|c|}{ Annual Energy Consumption for all cases } \\
\cline { 2 - 5 } & \multicolumn{1}{|c|}{ Aspects } & \multicolumn{1}{|c|}{ Annual electrical consumption (kwh) } \\
\cline { 3 - 5 } & & Case 1 & Case 2 & \multicolumn{1}{c|}{ Case 3 } \\
\hline 1 & Space cool & 17430 & 11890 & 12710 \\
\hline 2 & Ventilation fans & 52430 & 55530 & 58190 \\
\hline 3 & Area lighting & 60820 & 60820 & 60820 \\
\hline Total & & $\mathbf{1 3 1 3 5 0}$ & $\mathbf{1 2 8 8 9 0}$ & $\mathbf{1 3 2 3 6 0}$ \\
\hline
\end{tabular}

By analyzing, it is found that, the annual results of total energy consumption of case 1 is $46.30 \%$ in area lighting, $39.91 \%$ in ventilation fans, and remaining $13.79 \%$ for space cooling. Area lighting (AL) is same for all cases. Changes are there in space cool (SC) and ventilation fans (VF) in regarding changes in the materials as shown in Figure 9. As this study is the extension of the previous case study on single storey building, a comparison is made for better understanding.

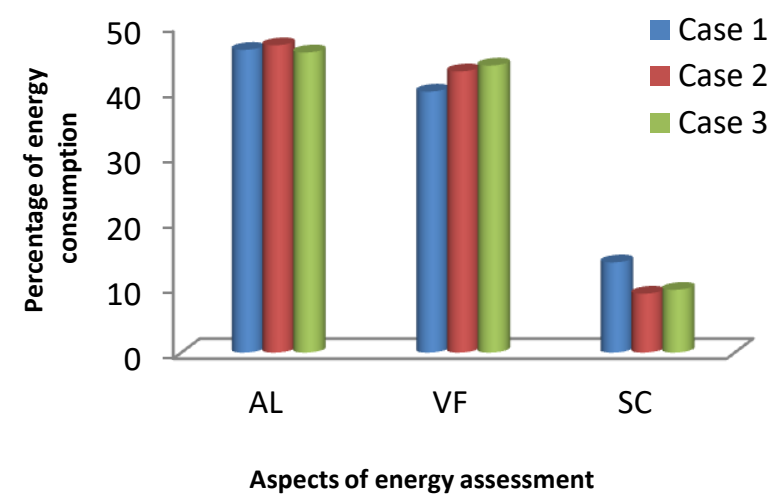

Fig. 8.Comparison of energy consumption Vs Energy assessment

B. Observations from single storey and six storey building

a) In single storey building four windows are present but for six storey building thirteen windows for present at each floor. The percentage of area used for windows in the single storey is $12.34 \%$ but in six storey its $29.25 \%$. Due to the presence of more number of windows, the energy consumed by utilizing the day lighting factor is more and because of that the electric consumption is less.

b) The electrical consumption for single storey varies for three cases that is for case 1 the area lighting is $72.20 \%$, for ventilation fans is $25.17 \%$ and for space cooling is 2.6 $\%$; For case 2 , the area lighting is $64.19 \%$, for ventilation fans is $30.48 \%$ and for space cooling is $5.3 \%$; For case 3 the area lighting is 64.97 $\%$, for ventilation fans is $30.85 \%$ and for space 
cooling is $4.16 \%$, But for the six storey for case 1 the area lighting is $46.30 \%$, for ventilation fans is $39.91 \%$ and for space cooling is $13.26 \%$; For case 2 the area lighting is $47.18 \%$, for ventilation fans is $43.08 \%$ and for space cooling is $9.2 \%$; For case 3 the area lighting is $45.95 \%$, for ventilation fans is $43.96 \%$ and for space cooling is $9.60 \%$.

c) In single storey building the electricity consumed for ventilation fans is less i.e.; $25 \%$. Comparatively for the six storey building it is $73 \%$. This is because in single storey building there is only one room with two fans but in six storey building there are fans and $\mathrm{AC}$ consuming so more electricity.

d) The percentage of electrical consumption for space cooling will be more during the months of May, June, July, August and September due the climatic conditions which comes under summer season. This concept remains same for both the six and single storey building.

\section{CONCLUSION}

The following conclusions are made from this study:

(a) It seems that there is no effect on the aspects of area lighting for all the three cases, since the electric consumption values are same.

(b) It is observed that the maximum electric consumption is for area lighting (around $46 \%$ ) than space cool and ventilation fan aspects.

(c) By changing the infill walls the electric consumption on space cool is increased by $32 \%$.

(d) By changing roof material the electric consumption is decreased by $20 \%$, since because wood is a thermal insulator, when using wood as a roof so it requires less energy to heat and cool and electricity bill also reduce.

(e) The effect of material behaviour is must to be incorporated in the design stage itself to reduce the energy consumption level.

\section{ACKNOWLEDGMENT}

The authors wish to express their thanks to Ms. V. Akila Reddy, Ms. G.C. Rithu Christy and Ms. S. Karthiga for their involvement in this work.

\section{REFERENCES}

1. J. Stokes and A. Horvath, "Life Cycle Energy Assessment of Alternative Water Supply Systems," International Journal of Life Cycle Assessment, vol. 11, pp. 335-343, Sep. 2006.

2. M. M. Khasreen, F. G. Banfil and G. F. Menzies, "Life Cycle Assessment and the Environmental Impact of Buildings: A Review," Sustainability, vol. 1, pp. 674-701, Sep. 2009.

3. T. Ramesh, Ravi Prakash and K. K. Shukla, "Life Cycle Energy Analysis of Buildings: An Overview," Energy and Buildings, vol. 42, pp. 1592-1600, Oct. 2010.

4. "An Executive Guide: Life Cycle Assessment," International Council of Chemical Associations, 2014.

5. A. M. F. De Araujo and S. F Tavares, "Building Life Cycle Energy Assessment on Pre-Operation Phase using BIM," Int. Conf. SBE 16, Brazil, Sep. 2016.

6. S. Soni, K. Chowdary and A. Sharma, "Institutional Building Energy Simulation," International Research Journal of Engineering and Technology, vol. 3, pp. 1160-1165, Nov. 2016.

7. A. S Sabnis, "Life Cycle Energy Analysis in Buildings and Sustainability Assessment: A Literature Review," June 2017.

8. C.Sivapragasam, PL.Meyyappan "Effect of Materials in Life Cycle Energy Assessment: - A Case Study of a Single Storey Building," March 2019.

\section{AUTHORS PROFILE}

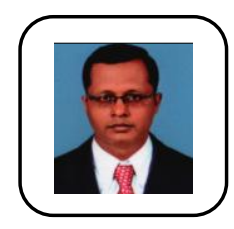

Dr. PL. Meyyappan has completed his graduation and post-graduation from Bharathiyar University and Karunya University respectively. He completed his $\mathrm{PhD}$ from Kalasalingam University. He has 13 years of teaching experience. He has completed 2 sponsored research projects from TNSCST and published more than 25 papers in peer reviewed journals and conferences. He is a life member in ISTE, IEI, IGS, ISET, ISRS. He is serving as Editorial Board Member and Reviewer in various reputed Journals.

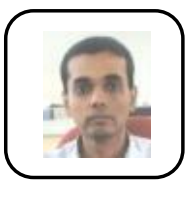

Dr. C.Sivapragasam has completed his graduation and post-graduation from IIT-Roorkee and IIT-Delh respectively. He completed his $\mathrm{PhD}$ from NUS, Singapore. He has 2 years of industry experience and more than 17 years of teaching experience. He has completed 3 sponsored research projects from various funding agencies and published more than 70 papers in peer reviewed journals and conferences..
Published By:
Blue Eyes Intelligence Engineering \& Sciences Publication 